\title{
CHEMICAL INVESTIGATIONS ON THE HYDROGRAPHICAL SYSTEM OF CANANÉIA LAGOON
}

(Received for publication in 1959)

\author{
KenJi Kato * \\ Faculty of Fisheries, Hokkaido University - Japan \\ Oceanographic Institute, University of São Paulo - Brazil
}

\begin{abstract}
SYNOPSIS
Periodical observations were made in 1958 in the hydrographical system of Cananéia lagoon State of São Paulo. The present paper reports the general characteristics of the regional distribution of chemical constituents in the water of the lagoon as observed on the February 11, 1958.

The outer sea water $\left(34 \%\right.$ salinity, $4.5 \mathrm{ml} / 1 \mathrm{O}_{2}, \mathrm{pH} 8.4,0.1 \mu$ g-atoms-nitrate$\mathrm{N} / 1,0.3 \mu$ g-atoms-phosphate-P/1 and $4 \mu$ g-atoms-silicate- $\mathrm{Si} / 1$ ) flows into the lagoon at flood tide through the Barra de Cananéia. The major portion of the inflowing sea water moves westward through the Baia de Trapandé pushing the inner lagoon water toward the northern sheltered region, while a smaller portion enters along the eastern waterway called Mar de Cananéia, but is apparently blocked in its flow because of the narrow passage. In the sheltered inner region the rise of the water level apparently depends upon an accumulation on the water of the tributaries which is blocked by the outer tidal wave.

The lowering of the water level of the open sea during the ebb sucks out the lagoon water, and a high velocity of the outflow through the narrow waterway of the Mar de Cananéia is then usually observed.

In the inner region of the lagoon when the horizontal movement of the water due to the tides is weakened, a reduction state is likely to develop in the bottom layer on account of active decomposition by bacteria of the deposited organic materials. Accordingly, considerable lowering of the oxygen tension is observed in the water overlying the bottom. In the surface water at the same station the amount of dissolved oxygen is near saturation point. The decomposing activity of the bacteria is very important for the lagoon's metabolism. The return of nutrients into the water undoubtedly contributes efficiently to enrich the phytoplankton crop.
\end{abstract}

\section{INTRODUCTION}

The studies reported in this paper were carried out at the Research Station of the Oceanographic Institute (University of São Paulo, Brazil) at Cananéia, on the Island of Cananéia on the south coast of the State of São Paulo in 1958.

The island of Cananéia is surrounded by the waters of a large lagoon and channel system which is $110 \mathrm{~km}$ long, reaching from the Barra do Ararapira (where the Ararapira channel begins) to the mouth of the Ribeira de Iguape river. This system is subdivided into smaller systems which are almost independent of each other from the hydrographic point of view (BESNARD 1950a, b).

* At present in the Faculty of Fisheries, Prefectural University of Mie, Tsu, Japan.
The lagoon region of Cananéia has been studied geographically by Prof. BESNARD, first director of the Oceanographic Institute, who also interested other scientists in its biological and geographical problems (Besnard 1950a, b; Ab'Sáber \& Besnard 1953; Carvalho 1950; Carvalho \& Chermont 1952; SADOWSKY 1952, 1953, 1954; Bigarella 1954). However very few data are available on the chemical properties of the water and of the sediments in the lagoon. The hydrographic and chemical investigations of Machado $(1950 ; 1952)$ did not permit an explanation of the geochemical aspects of the whole lagoon system. No investigations on the organic productivity and on the geo- and biochemical properties of these waters have been carried out in Brazil up to now. 
The present research is a contribution towards the knowledge of the fundamental hydrochemical properties of the lagoon waters as well as a survey of the regional distribution of nutrients in relation to the organic production of the lagoon water.

The hydrographical properties of the water are influenced chiefly by tidal fluctuations and by the discharge of runoff from land into the lagoon. The hydrography is also influenced by the coastal wind prevailing in the region and by geochemical changes caused by mixing of coastal sea water with the mangrove "river" water. These "rivers" or "marigots" (BESNARD 1950a, b) are in most cases channels or creeks containing marine tidal waters and fresh-water from the mangrove flats.

\section{MATERIAL AND METHODS}

Nine geochemical observations were made as summarized in Table I.

The Petersen-Nansen insulated water bottle was used to collect water samples at known depths. Rou- tine observations on temperature, salinity, oxygen, $\mathrm{pH}$, phosphate, silicate and nitrate were made on the water of the samples. Measurements of temperature and $\mathrm{pH}$ as well as fixation of the dissolved oxygen were made on board as quickly as possible immediately after sampling; $\mathrm{pH}$ was measured by means of a portable glass-electrode $\mathrm{pH}$-meter (Metrohm, Type E 280) and oxygen by WINKLER's method. Samples for determining silicate content were stored in polyethylene bottles so as to avoid dissolving of silicate from the glass-bottle. Nitrate, phosphate and silicate were determined on the day following sampling. Nitrate was determined by $\mathbf{M A}_{\mathrm{A}}$ CHIDA's modification of the reduced strychnine method, phosphate by DENIGÉs and ATKINs' method; and silicate by DIENERT and WANDENBUlKE's method. A Coleman Universal Spectrophotometer Model 14 was used in determining the quantities of these nutrients. Titration of dissolved oxygen was also done in the laboratory at Cananéia. The determination of the salinity of the water samples was done at the chemical laboratory of the Institute in São Paulo using MoHr and Knudsen's method.

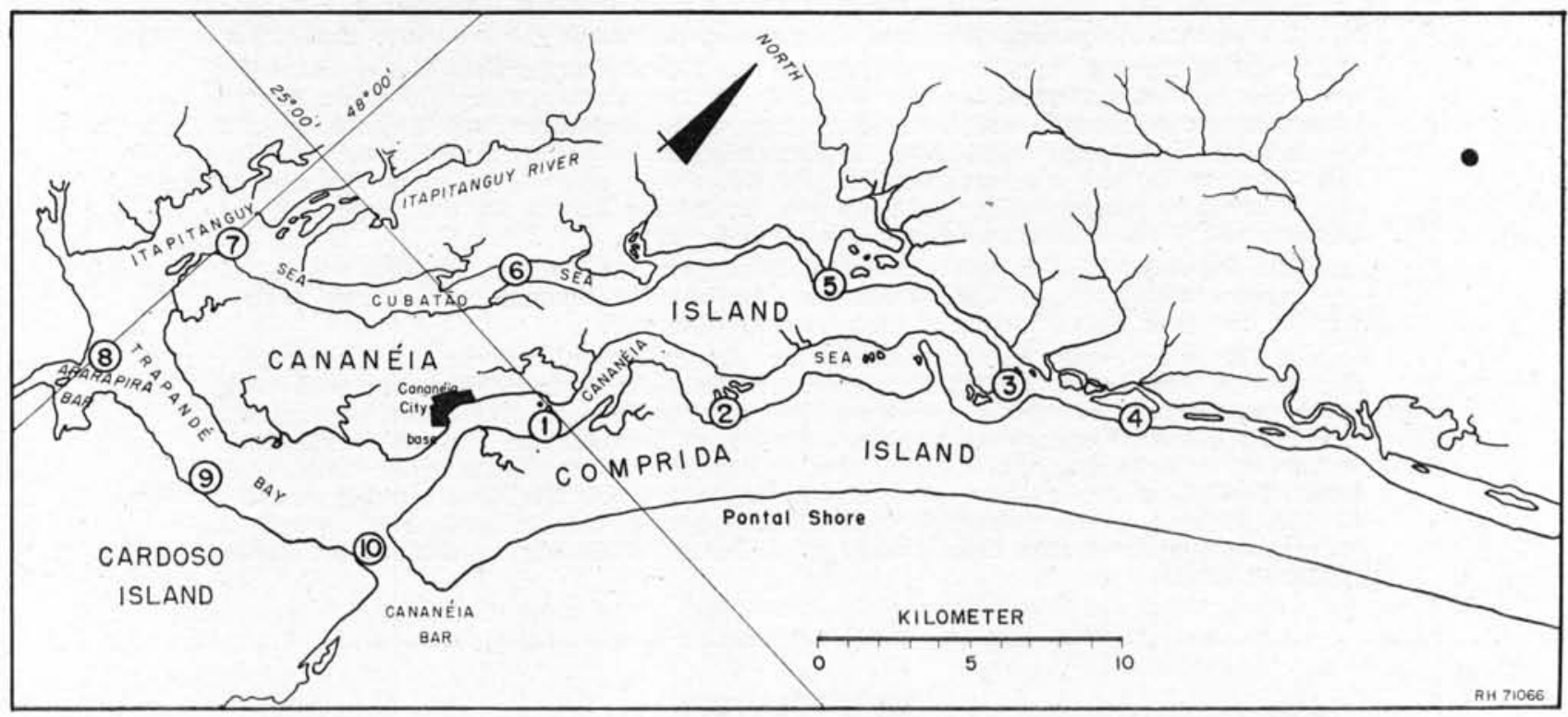

Fig. 1 - Lagunar region of Cananéia (Mar Pequeno) showing the stations positions.

GENERAL FEATURES OF THE REGIONAL DISTRIBUTION OF CHEMICAL CONSTITUENTS IN THE WATER OF THE CANANEIA LAGOON

To avoid the effect of tides and winds the day chosen for the collection of data on the chemical constituents of the lagoon water was a calm day when the difference between the tidal levels at high and low water was reduced to a minimum. On the $11^{\text {th }}$ February, 1958 the tidal gauge indicated only $20 \mathrm{~cm}$ in the tidal level difference and the wind velocity was low, approximately $0.2 \mathrm{~m} / \mathrm{sec}$. while the observations were being carried out. These required eleven hours, from 07.30 to 18.30. They were made from a motor boat at ten stations dis. tributed so as to cover the whole channel region around Cananéia Island (Fig. 1). Forty water samples were collected.

The results of the observations made in February are shown in Table II and the distribution of the chemical constituents in the lagoon water are illustrated in Figures 2-15.

The bottom topography of the lagoon is so complicated and variable and cannot be shown in detail until a through survey of the whole area is made. A reliable map of the topography of the whole lagoon region could not be found for the present work. Thus, the bottom topography of the lagoon was only represented as a succession of straight lines connecting the observed stations. 
TABLE I - Periodical observations in Cananéia (1958)

\begin{tabular}{|c|c|c|c|c|c|}
\hline Obs. ne & Date & $\begin{array}{l}\text { Stations } \\
\text { obs. }\end{array}$ & $\begin{array}{l}\text { Samples } \\
\text { collected }\end{array}$ & Chemical properties determined & $\begin{array}{l}\text { Articles of } \\
\text { analyses }\end{array}$ \\
\hline 1 & January, $16-22$ & 11 & 39 & Temp., pH, $\mathrm{O}_{2}, \mathrm{NO}_{2}, \mathrm{NH}_{4}, \mathrm{Cl}$ & 273 \\
\hline 2 & February, 10-13 & 10 & 40 & Temp., pH, $\mathrm{O}_{2}, \mathrm{NO}_{3}, \mathrm{P}_{2}, \mathrm{O}_{3}, \mathrm{SiO}_{2}, \mathrm{Cl}$ & 280 \\
\hline 3 & March, 26-28 & 6 & 9 & Temp., $\mathrm{pH}, \mathrm{O}_{2}, \mathrm{Cl}$, Redox-potential & 48 \\
\hline 4 & April, $24-27$ & 7 & 7 & Temp., pH, $\mathrm{O}_{2}, \mathrm{Cl}$, Redox-potential & 37 \\
\hline 5 & May, 25-29 & 2 & 10 & Temp., pH, $\mathrm{O}_{z}, \mathrm{NO}_{z}, \mathrm{P}_{2}, \mathrm{O}_{z}, \mathrm{SiO}_{z}, \mathrm{Cl}$ & 70 \\
\hline 6 & June, $8-13$ & 9 & 37 & Temp., pH, $\mathrm{O}_{z}, \mathrm{NO}_{3}, \mathrm{P}_{2}, \mathrm{O}_{r}, \mathrm{SiO}_{2}, \mathrm{Cl}$ & 279 \\
\hline 7 & July, $28-$ August, 2 & 51 & $\begin{array}{l}50 \\
\text { (sediments) }\end{array}$ & $\begin{array}{l}\text { Temp., } \mathrm{pH} \text {, humidity, Org. matter, } \\
\text { Total-N }\end{array}$ & \\
\hline & & & $\begin{array}{c}26 \\
\text { (water) }\end{array}$ & Temp., $\mathrm{pH}, \mathrm{O}_{2}, \mathrm{Cl}$ & 104 \\
\hline 8 & September, 21-25 & 13 & 48 & Temp., $\mathrm{pH}, \mathrm{O}_{2}, \mathrm{P}_{2}, \mathrm{O}_{3}, \mathrm{SiO}_{2}, \mathrm{Cl}$ & 288 \\
\hline 9 & December, 2-6 & 10 & 40 & Temp., $\mathrm{O}_{2}, \mathrm{Cl}$ & 120 \\
\hline Total & & 119 & 307 & & 1749 \\
\hline
\end{tabular}

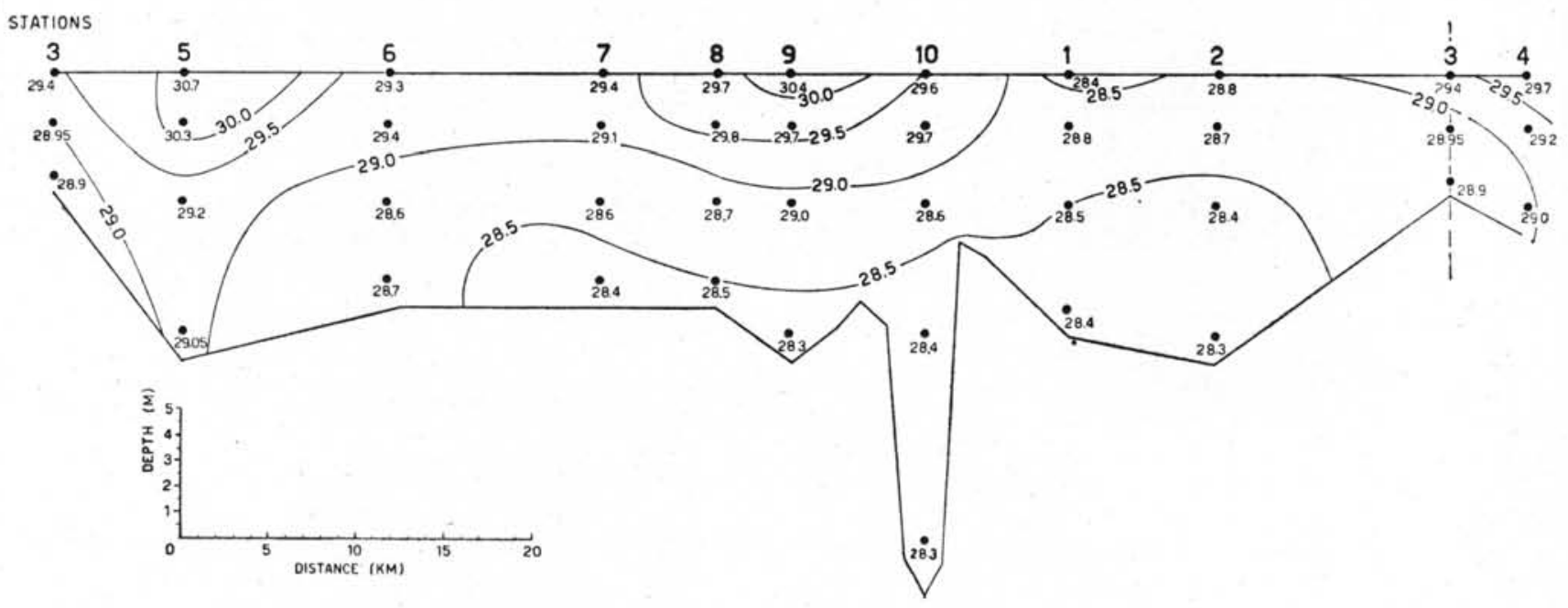

Fig. 2 - Water temperature $\left({ }^{\circ} \mathrm{C}\right)$, Cananéia lagoon.

\section{1) WATER TEMPERATURE}

Since most of the lagoon is comparatively shallow, the depths ranging from 3 to $6 \mathrm{~m}$ approximately, the water temperature is greatly influenced by the solar radiation. Accordingly it should not be used in the hydrographic discussion of the characters of the lagoon water system. The water of higher salinity from the open sea generally contributes to lower the temperatures, for example $28.3^{\circ} \mathrm{C}$ as compared with $30.0^{\circ} \mathrm{C}$ for the inner lagoon water, at the time the observation was made.

\section{2) SAlinity}

The sea water (Fig. 3) with $30-33.8 \%$ salinity flows into the lagoon region over the bar (Barra de Cananéia) and divides into a major portion which flows westwards into Baía de Trapandé approaching the Mar de Itapitanguí near to Mar de Cubatão, and another portion which blocks the outflow of the lagoon water in the Mar de Cananéia and inflows at a deeper layer, near the Ilha do Boqueirão at St. 2 . 


\begin{tabular}{|c|c|c|c|c|c|c|c|c|c|c|c|c|}
\hline & $\begin{array}{l}\vec{w} \\
\vdots \\
0 \\
0\end{array}$ & \multirow{3}{*}{ 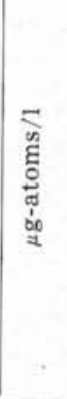 } & สิनีศ & † में & $\mathscr{\infty} \infty \infty \infty$ & ్ㅟ్ㅠ] & 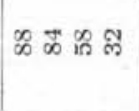 & ๑̊न & $F^{\infty} \infty \infty$ & $\bigoplus \overbrace{-1} \infty \infty$ & $\infty \infty \infty \infty$ & $\infty \infty \pi \forall+$ \\
\hline & $\begin{array}{l}0 \\
0 \\
0=1\end{array}$ & & 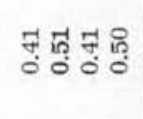 & 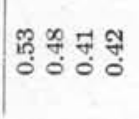 & ש: & 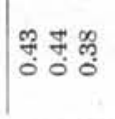 & 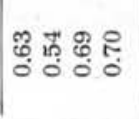 & 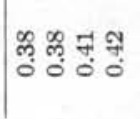 & 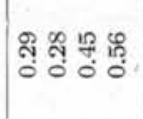 & 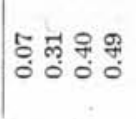 & 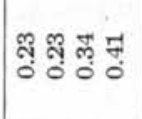 & 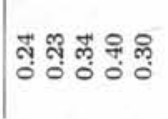 \\
\hline & $\begin{array}{l}z \\
\vdots \\
\text { zo }\end{array}$ & & 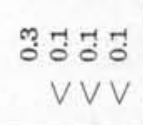 & 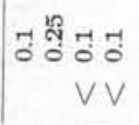 & 붕 ํㅕㅇ & 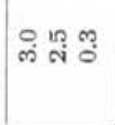 & 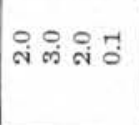 & 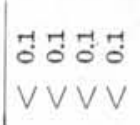 & 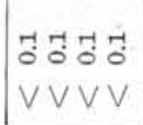 & 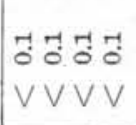 & 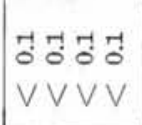 & 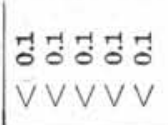 \\
\hline \multirow{3}{*}{ 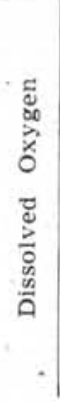 } & 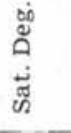 & $\hat{8}$ & 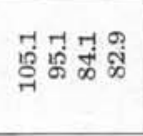 & भุต & 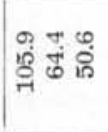 & 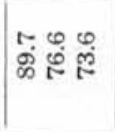 & $\begin{array}{l}\omega \\
\infty \\
\infty\end{array}$ & 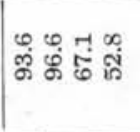 & 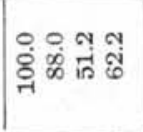 & 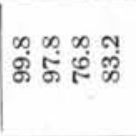 & 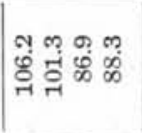 & 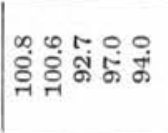 \\
\hline & $\begin{array}{l}\text { 峞 } \\
0^{\prime \prime}\end{array}$ & $\widehat{\widehat{્}}$ & 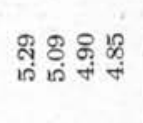 & 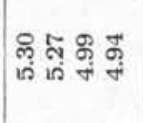 & 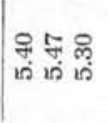 & 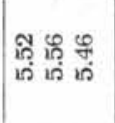 & 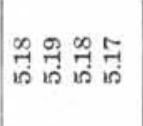 & 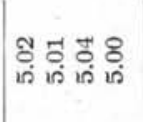 & 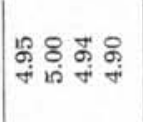 & 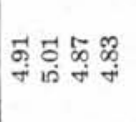 & 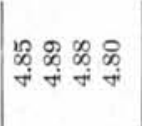 & 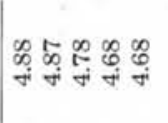 \\
\hline & & $\widehat{\widehat{\Xi}}$ & 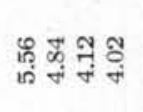 & 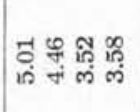 & 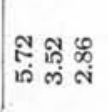 & 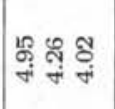 & 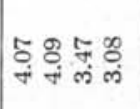 & 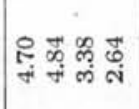 & 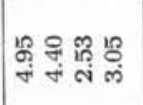 & 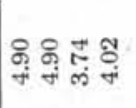 & 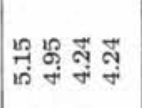 & 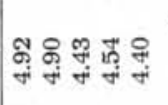 \\
\hline \multicolumn{3}{|c|}{ 票 } & 究 & 蛋 & 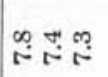 & 兽: & 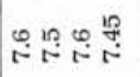 & 잉 & 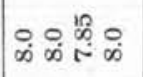 & 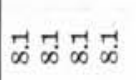 & 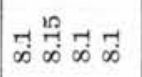 & 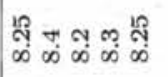 \\
\hline \multicolumn{2}{|l|}{ 咅 } & $\frac{1}{8}$ & 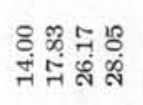 & 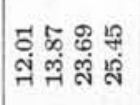 & 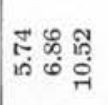 & 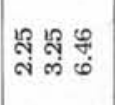 & 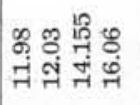 & 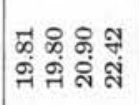 & 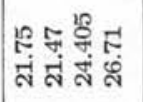 & 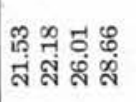 & 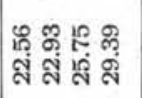 & 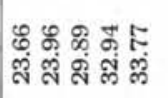 \\
\hline \multicolumn{2}{|l|}{ 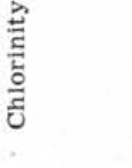 } & $\frac{1}{\vdots}$ & 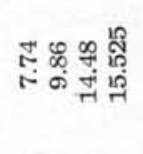 & 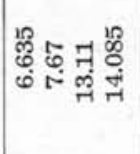 & 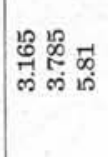 & 旁点怘 & 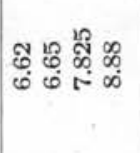 & 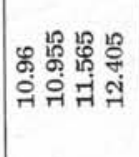 & 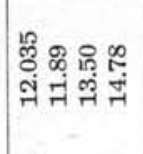 & 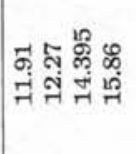 & 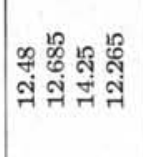 & 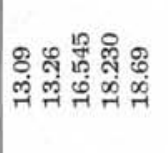 \\
\hline 总 & & ชิ & 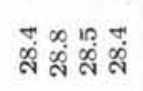 & $\begin{array}{l}\infty \\
\infty \\
\dot{\alpha} \\
\dot{\alpha}\end{array}$ & 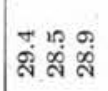 & テี สุ สิ & 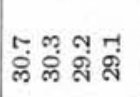 & 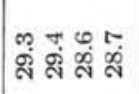 & 落 & 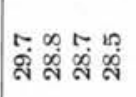 & 范 & 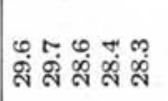 \\
\hline 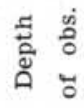 & & $\widehat{\mathrm{g}}$ & ON $N$ in & O N in & ONT & O & ON & $0 \times$ in $\infty$ & O N 20 & O $N \backsim \infty$ & ON in $\mathrm{g}$ & ○ N \\
\hline を 宊 & & రิ & เู่ & 范 & $\stackrel{\infty}{\infty} \underset{\infty}{\infty}$ & 望 & @̊̀ & ลุ & rid & ัั่ & สุ & $\begin{array}{l}\text { in } \\
\stackrel{\leftrightarrow}{8}\end{array}$ \\
\hline 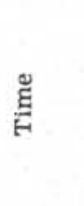 & & 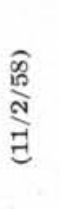 & 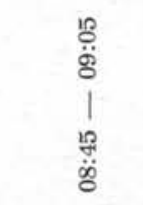 & 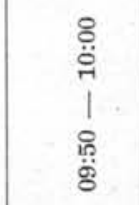 & 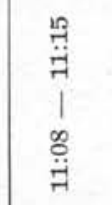 & 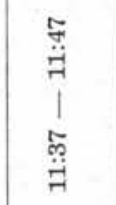 & 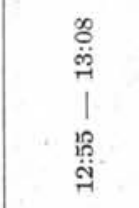 & 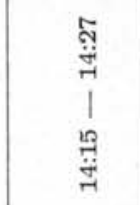 & 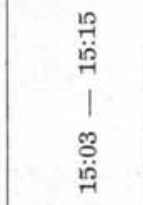 & 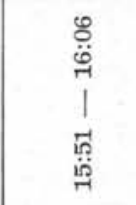 & 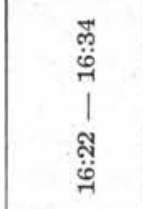 & 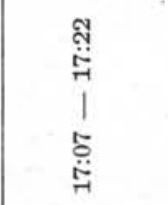 \\
\hline 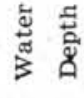 & & छ్ & 국 & 7 & 苧 & 0 & 7 & o & $\infty$ & o & $F$ & สิ \\
\hline 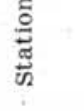 & & $\dot{z}$ & $r$ & N & in & $\sigma$ & ฉ & 0 & N & $\infty$ & o & 아 \\
\hline
\end{tabular}


At the same time fresh water of about $2 \%$ salinity flows southwards along the narrow waterway from Iguape, runs into and mixes with the brackish water of the lagoon at a place where three waterways join, (St. 3), near the northern end of Cananéia Island.

The salinity distribution in the lagoon shows the following pattern of flow into and from coastal waters with the tides:

A) During flood sea water enters the lagoon from Barra de Cananéia and its major portion flows westward through Baía de Trapandé pushing the inner lagoon water toward the northern upper reaches of the channel. The other smaller portion of sea water seems to be almost blocked in its flow into the Mar de Cananéia channel. Consequently the water level at the upper region of the lagoon i.e. Mar de Cananéia and Mar de Cubatão rises and with the added accumulation of fresh water from the affluents, blocks the outer tidal flood.
B) During ebb tide however, the hydrography of the lagoon looks somewhat different. The lowering of the tidal level acts like the suction of a syringe causing the inner water, which has been more or less mixed with sea water, to flow outward to the open sea. The suction is more evident in the eastern narrow waterway, or Mar de Cananéia, where the ebb current gains a fairly high velocity.

At St. 5, in the vicinity of the estuary of Rio Guatapará, there is the meeting point of waters which coming from opposite directions would most likely meet due to the tides and remain in hydrodynamical balance, at that point. In an area like this the horizontal movement of the water is usually minimum and the rise of the water level is mostly attributed to the accumulation of inflowed waters as well as to the supply of fresh water from the affluents. This also brings about another characteristic of the hydrography of the area with relation to nutrient distribution in the lagoon water as will be mentioned later.

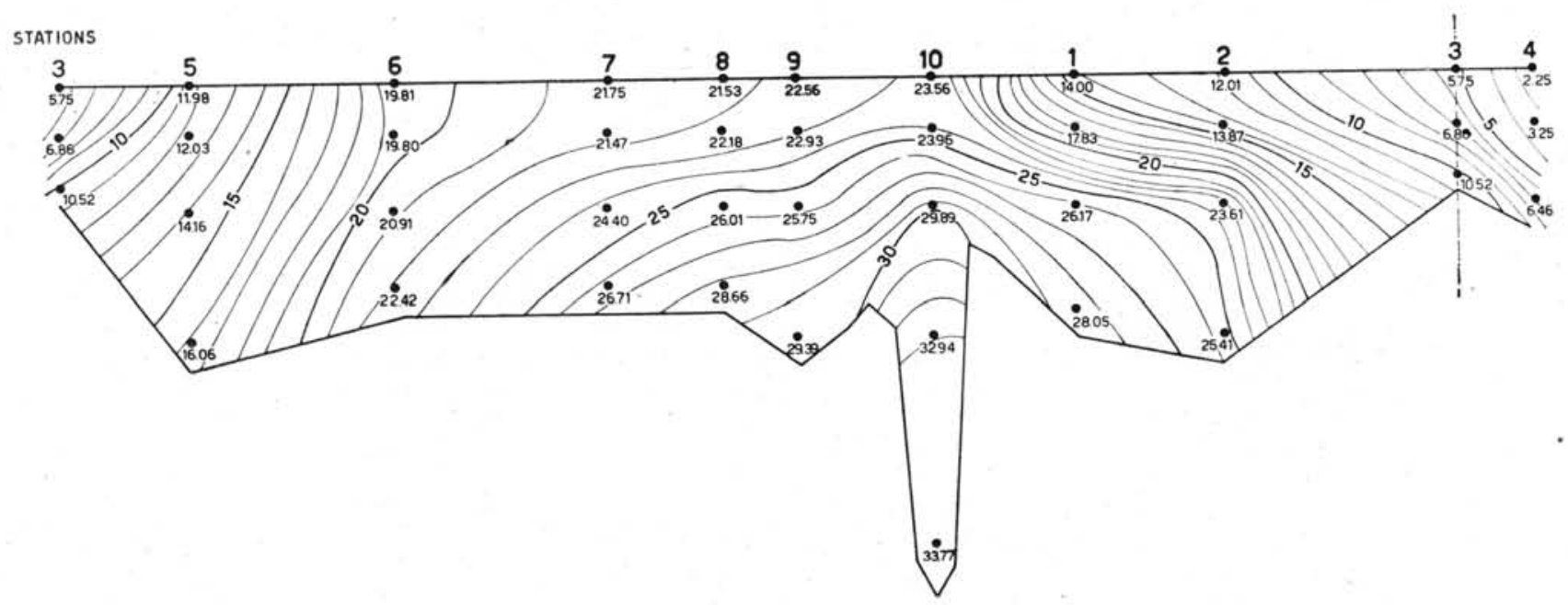

Fig. 3 - Salinity $(\%)$, Cananéia lagoon.

\section{3) Dissolved oxygen}

Regional distribution of dissolved oxygen in the lagoon water is of considerable interest from the point of view of photosynthesis of the phytoplankton and bacterial consumption of oxygen. The sea water is almost saturated with oxygen and has about 4.5 $\mathrm{ml} / \mathrm{l}$, while the oxygen content of the inner water of the lagoon, particularly the bottom layer decreases according to the state of reduction over or within the bottom sediments. The reduced state is probably correlated with bacterial action.

Supersaturation of dissolved oxygen to $105 \%$ occurs in the surface layer at three stations in the lagoon, as shown in Fig. 8. This supersaturation of oxygen is certainly due to active photosynthesis caused by the rapid development of phytoplankton populations at these stations. Of course, the biological character of the phytoplankton populations probably depends upon the hydrographic and geochemical conditions of the water. Therefore, phytoplankton species adapted to the regional variation of physical and chemical characteristics of the water should be found at the above three stations. Presumably the predominant populations found at the two stations near the entrance (St. 1 and 9) are adapted to marine conditions while those at the interior stations like St. 3 are of brackish or freshwater types. That is to say, at the former stations there is probably a region where hydrographical 
balance occurs between the outer oceanic water and the inner water of the lagoon. There, oceanic phytoplankton populations from the outer sea water will accelerate their development on receiving a large supply of nutrients from the lagoon water. At St. 3 , brackish lagoon water is markedly diluted by the almost fresh-water from the narrow waterway. In consequence an optimum environment for the active development of limnological phytoplankton populations is formed at this point. As no biological data have been collected thus far, it is as yet impossible to check the correlation which probably occurs between the phytoplankton populations and the physicochemical environment of the lagoon region.

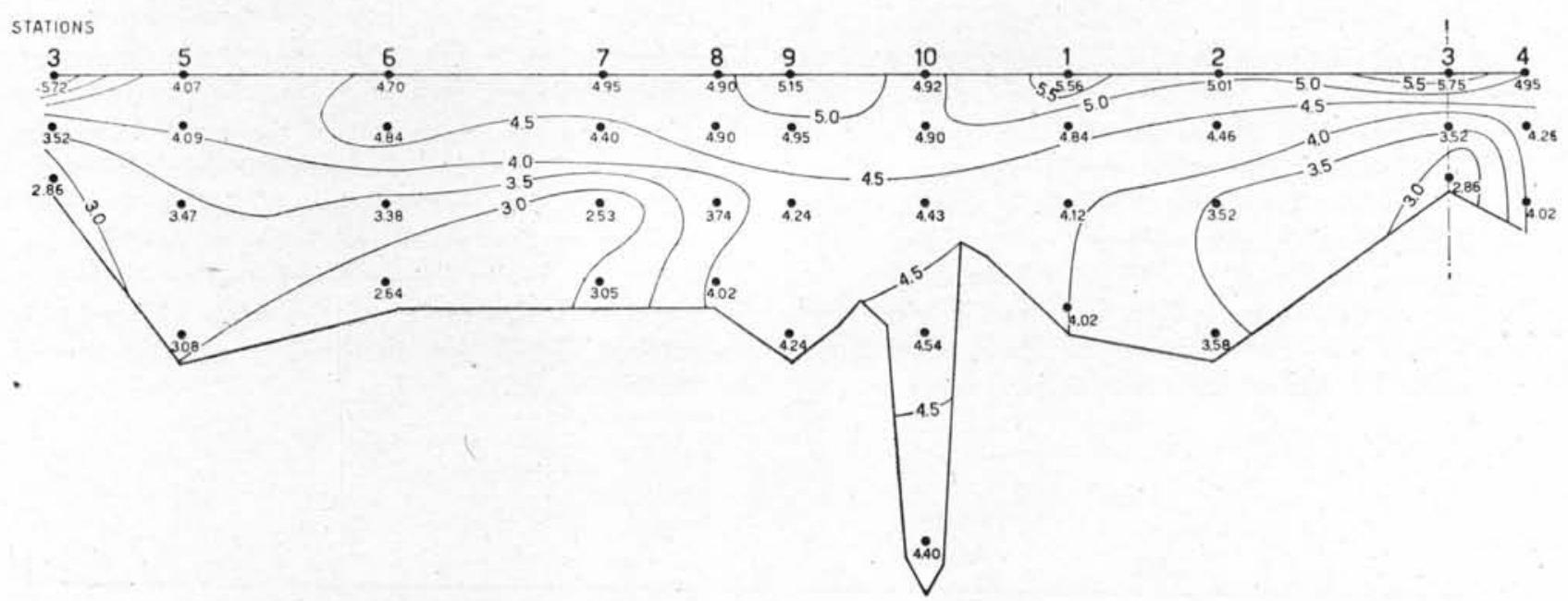

Fig. 4 - Dissolved oxygen $(\mathrm{ml} / 1)$, Cananéia lagoon.

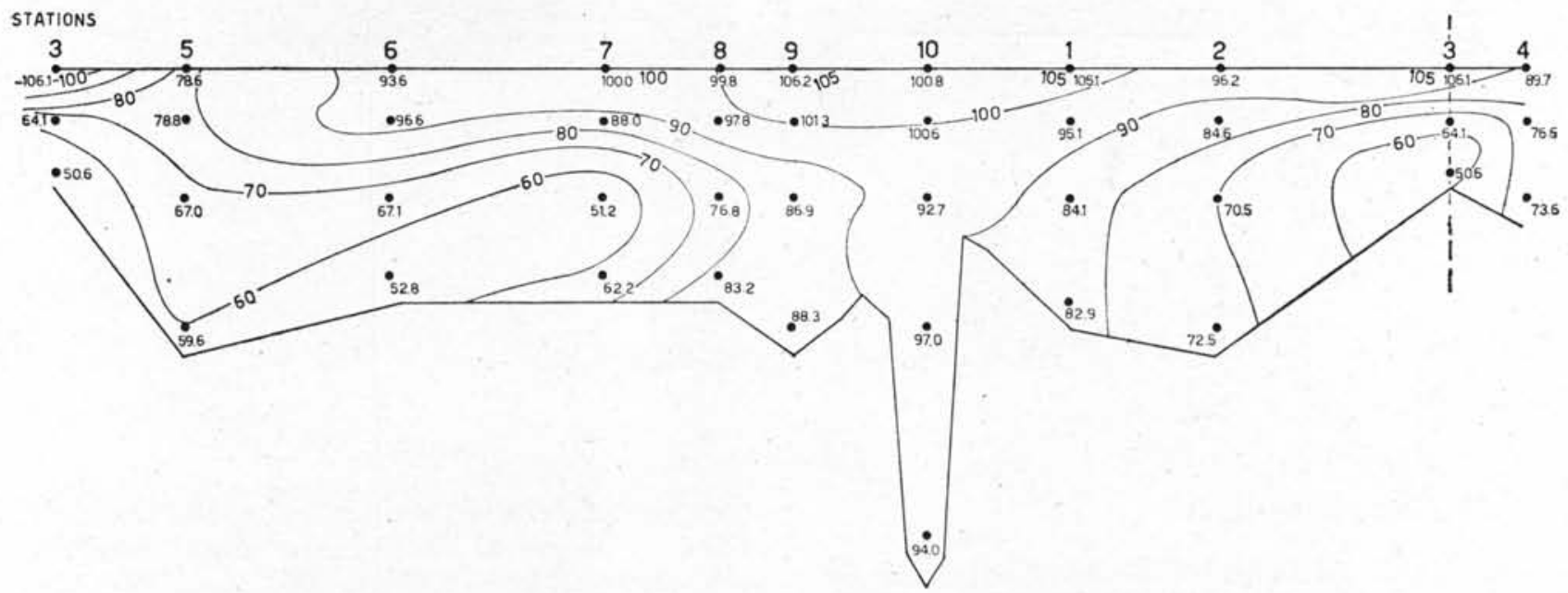

Fig. 5 - Saturation percentage of dissolved oxygen $(\%)$ in Cananéia lagoon.

\section{4) Hydrogen-Ion CONCEntration}

Regional variation of $\mathrm{pH}$ in the lagoon water is of interest when studied in connection with those of salinity and dissolved oxygen content.

The $\mathrm{pH}$ of outer sea water is 8.4 while most of the lagoon water has $\mathrm{pH}$ of about 7.9. It is note- worthy that the bottom water which is mostly in a state of reduction has in general a relatively lower value of $\mathrm{pH}$ as compared with the surface water. This lower $\mathrm{pH}$ is caused by bacterial decomposition of organic materials deposited in the bottom. Such a biochemical lowering of the $\mathrm{pH}$ was especially remarkable at the bottom in St. 3 . 


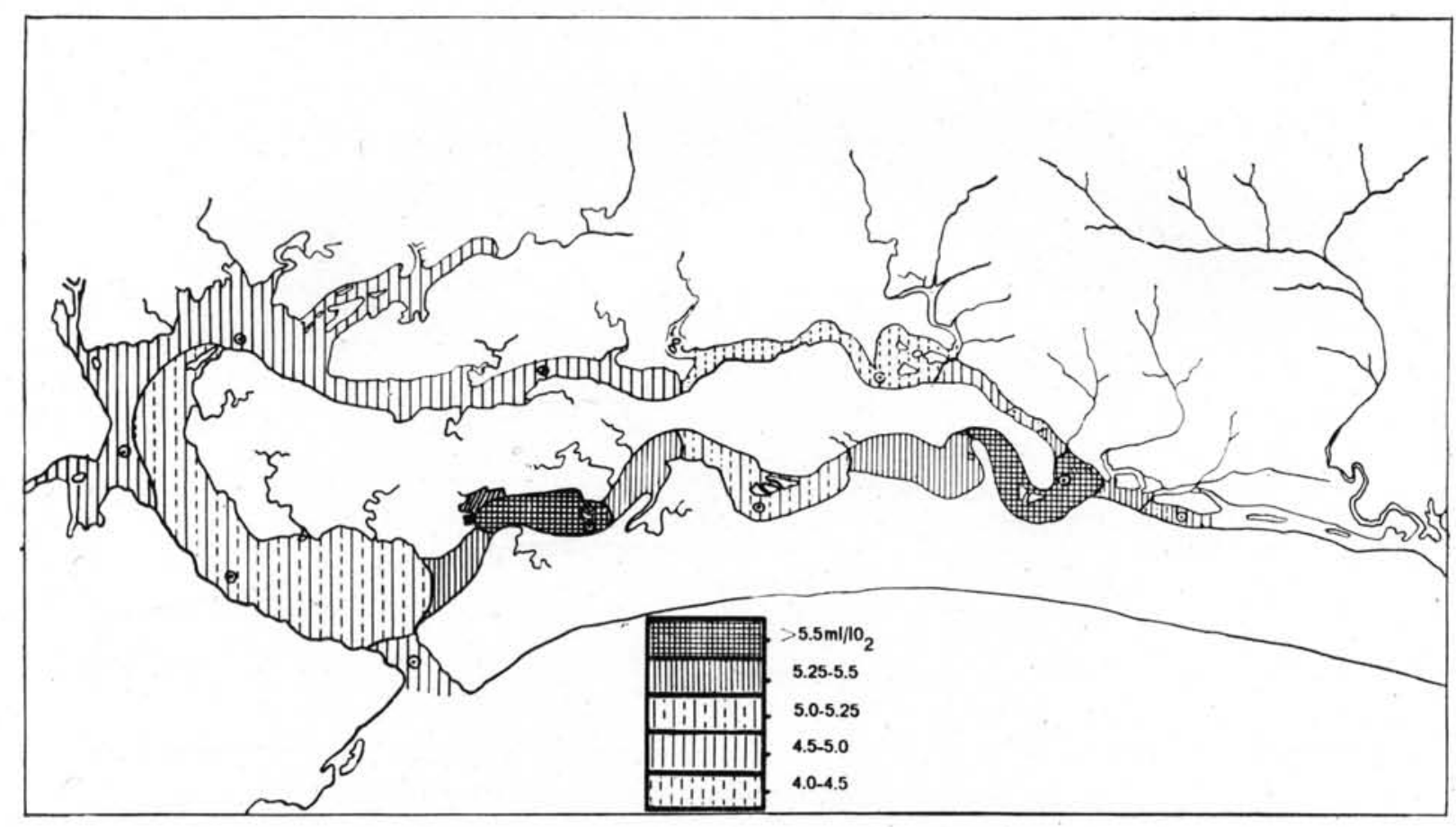

Fig. 6 - Distribution of dissolved oxygen in Cananéia lagoon (bottom layer).

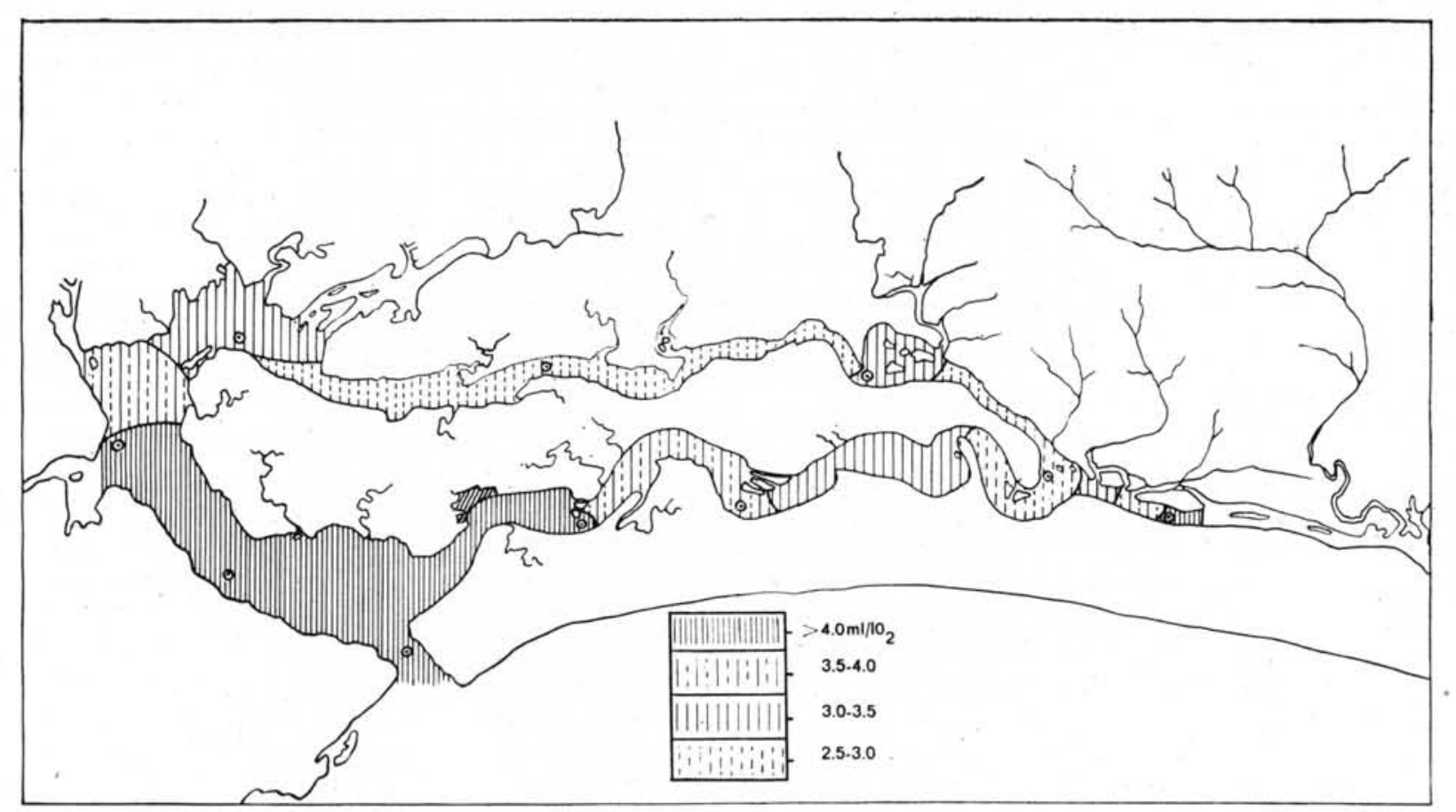

Fig. 7 - Distribution of dissolved oxygen in Cananéia lagoon (surface layer). 


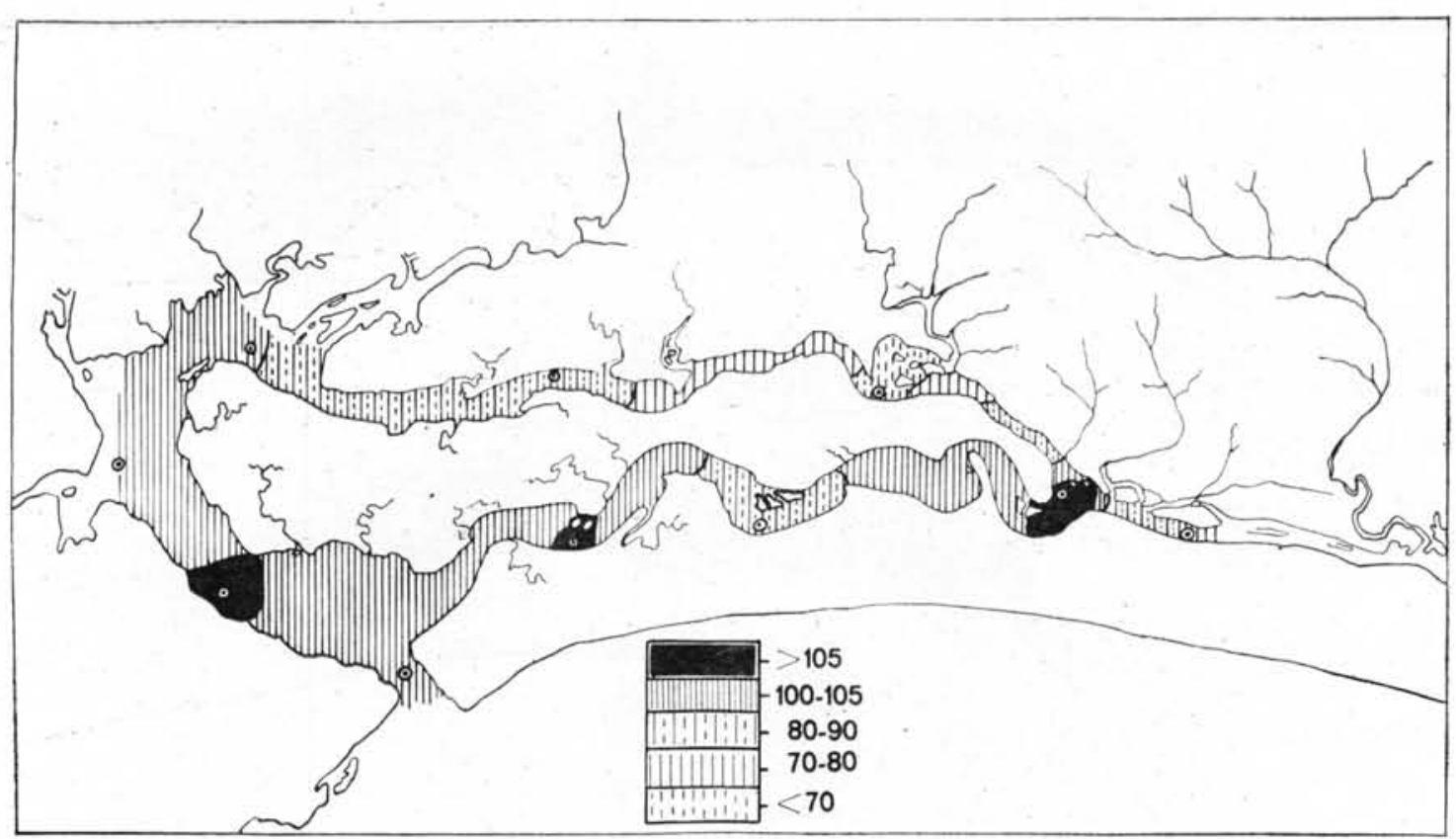

Fig. 8 - Distribution of saturation percentage of oxygen in Cananéia lagoon (surface layer).

\section{5) Silicates}

The amount of silicate in the coastal water is greatly influenced by the land water with an abundant quantity of silicate. Accordingly the distributional aspect of the silicate content in the lagoon is probably the inverse of the salinity. Land water with abundant quantity of silicate, as much as 120 $\mu$-atoms-Si/l, flows into the lagoon through the narrow waterway (St. 4) and spreads into the Mar de Cananéia and Mar de Cubatão, mixing with the inflowing sea water, the silicate content of which is as low as $3.7 \mu \mathrm{g}$ atoms.

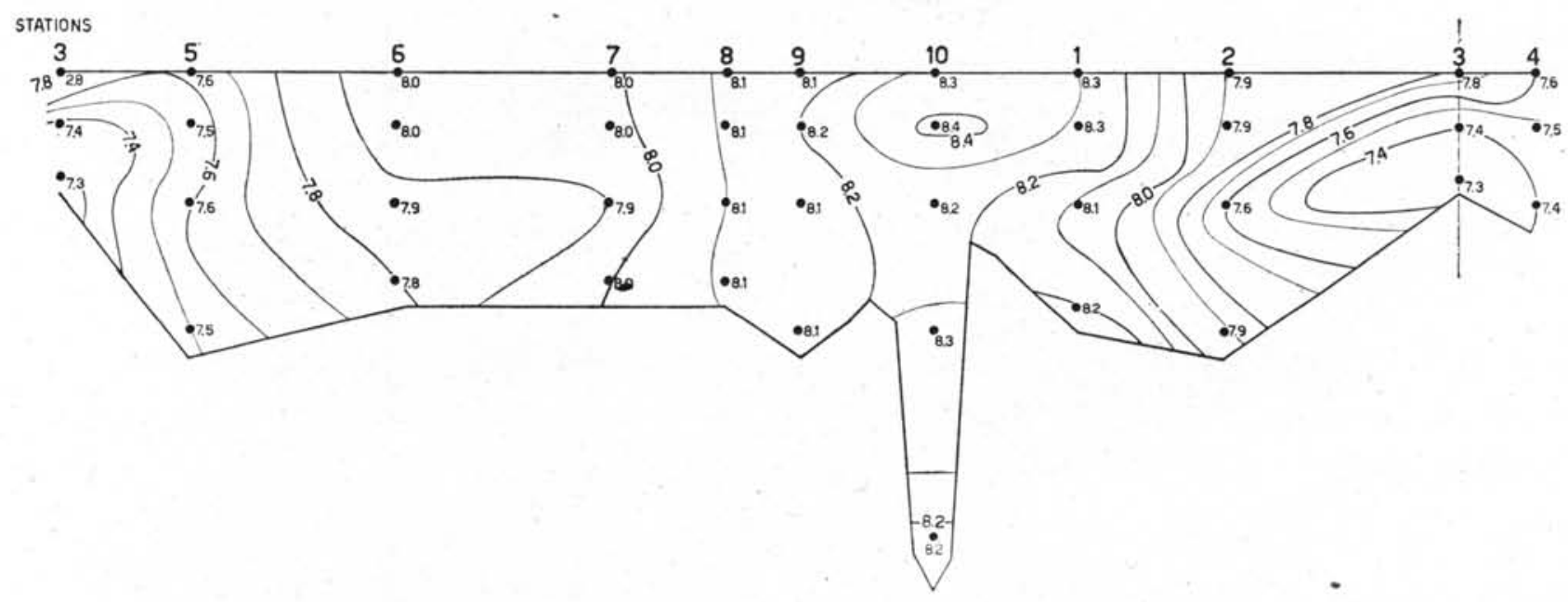

Fig. 9 - Hydrogen-ion concentration (pH), Cananéia lagoon. 


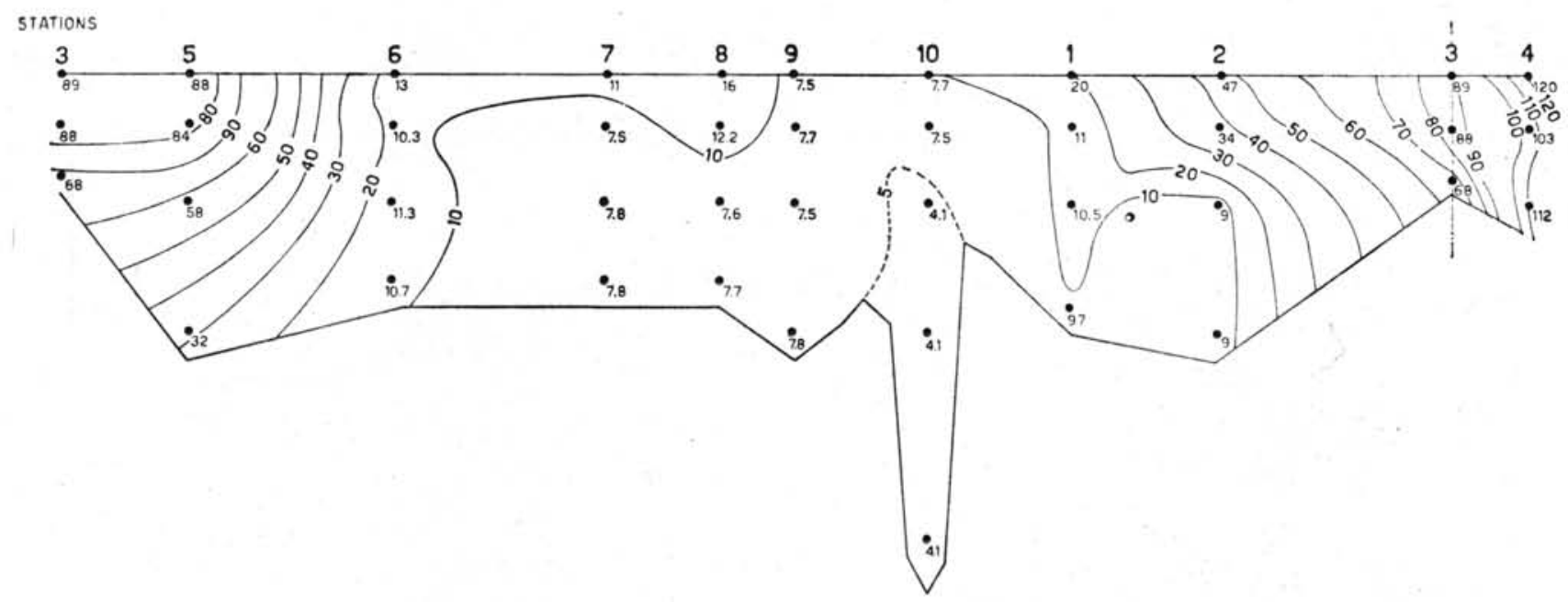

Fig. 10 - Silicate-Si ( $\mu$ g-atoms-Si/1), Cananéia lagoon.

\section{6) Phosphates}

The outer water contains a relatively low content of phosphates, up to $0.3 \mu \mathrm{g}$-atoms-P/l, and differs from the bottom water at the inner part of the lagoon where a fair amount of phosphate is found. The accumulation of phosphate in the bottom layer is closely related to the amount of dissolved nutrients produced by bacterial decomposition of organic detritus which is suspended in the bottom layer or deposited on the sediments. As the return of phosphorus into the water is likely to promote the active growth of phytoplankton, it follows that the oxygen content in the upper layer of water will increase markedly with active photosynthesis. This biochemical aspect is outstanding in the surface layer of an interior station like St. 3. Here a characteristic supersaturation of oxygen over $105 \%$ was observed in the surface layer in spite of a remarkable fall of oxygen tension due to bacterial consumption, at the bottom. As pointed out above it is noteworthy that the return of the nutrients into the overlying water contributes greatly to the organic production in the present lagoon. Therefore another study will be carried out to estimate the budget of organic consumption and the geo-biochemical return of nutrients from the bottom sediments of this lagoon.

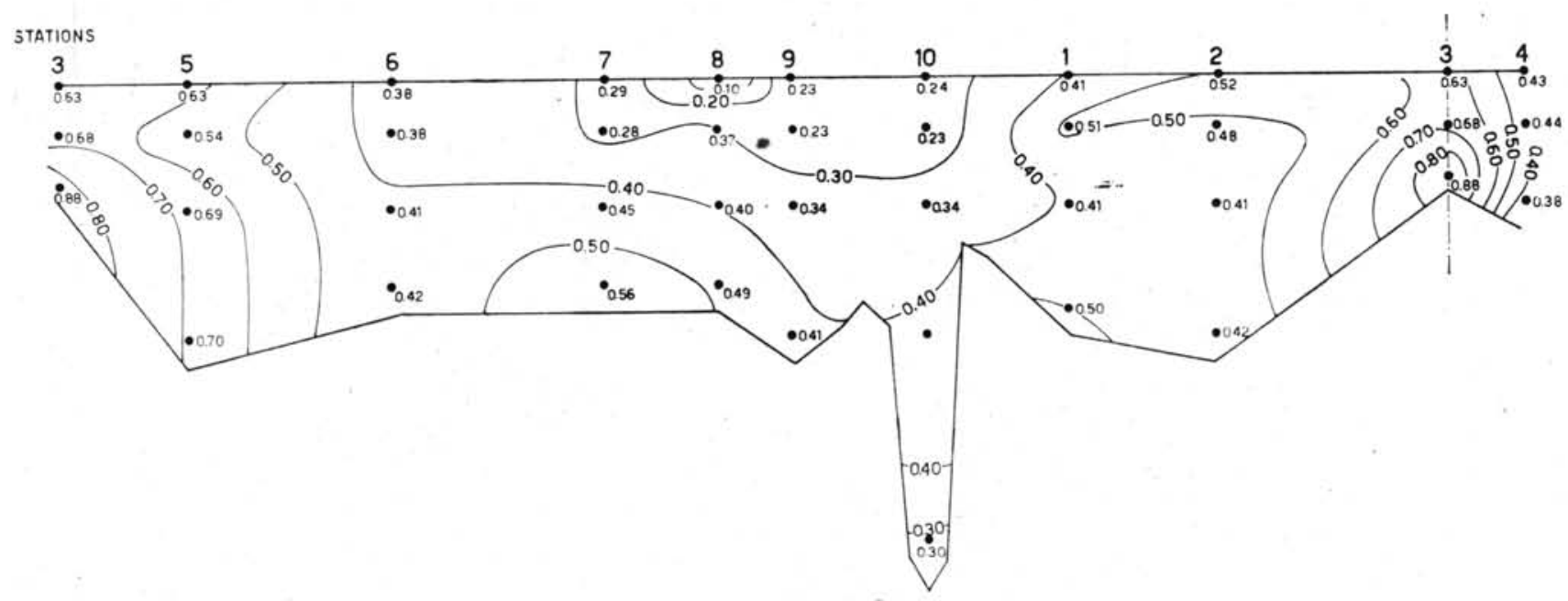

Fig. 11 - Phosphate-P ( $\mu$ g-atoms P/1), Cananéia lagoon.

\section{7) Nitrate $\dot{S}$}

The distribution of nitrate in this lagoon is important in connection with the hydrography of the lagoon water and as a biochemical factor of organic production.
As illustrated in Figures 14 and 15, a remarkable accumulation of nitrate is found in the interior region of the lagoon, at St. 5 and 4 , whereas an extremely low content, below $0.1 \mu \mathrm{g}$-atoms-N/1 of nitrate, is found in the open area near the southern entrance of the lagoon. The plankton population 


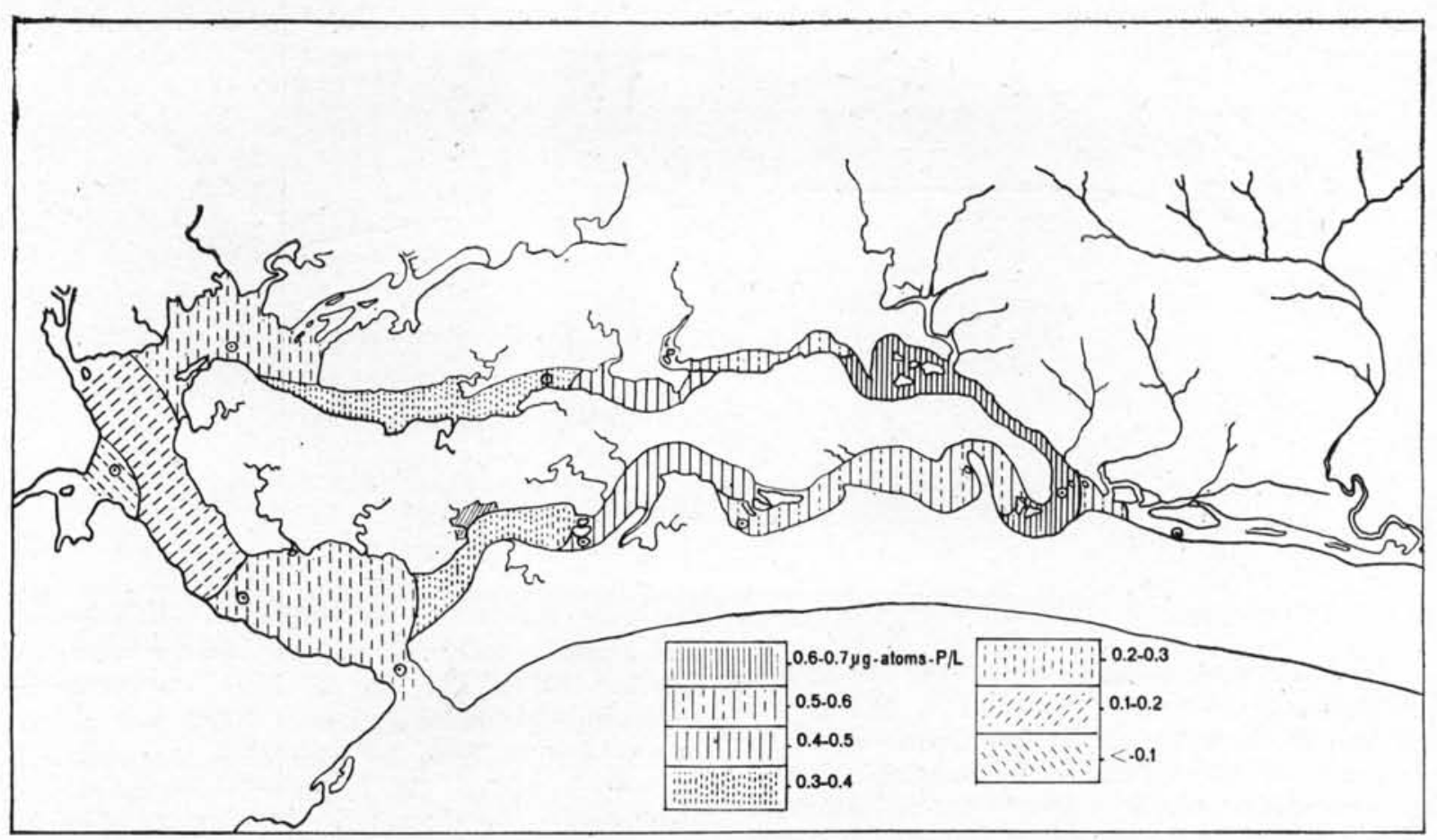

Fig. 12 - Distribution of phosphate-P in Cananéia lagoon (surface layer).

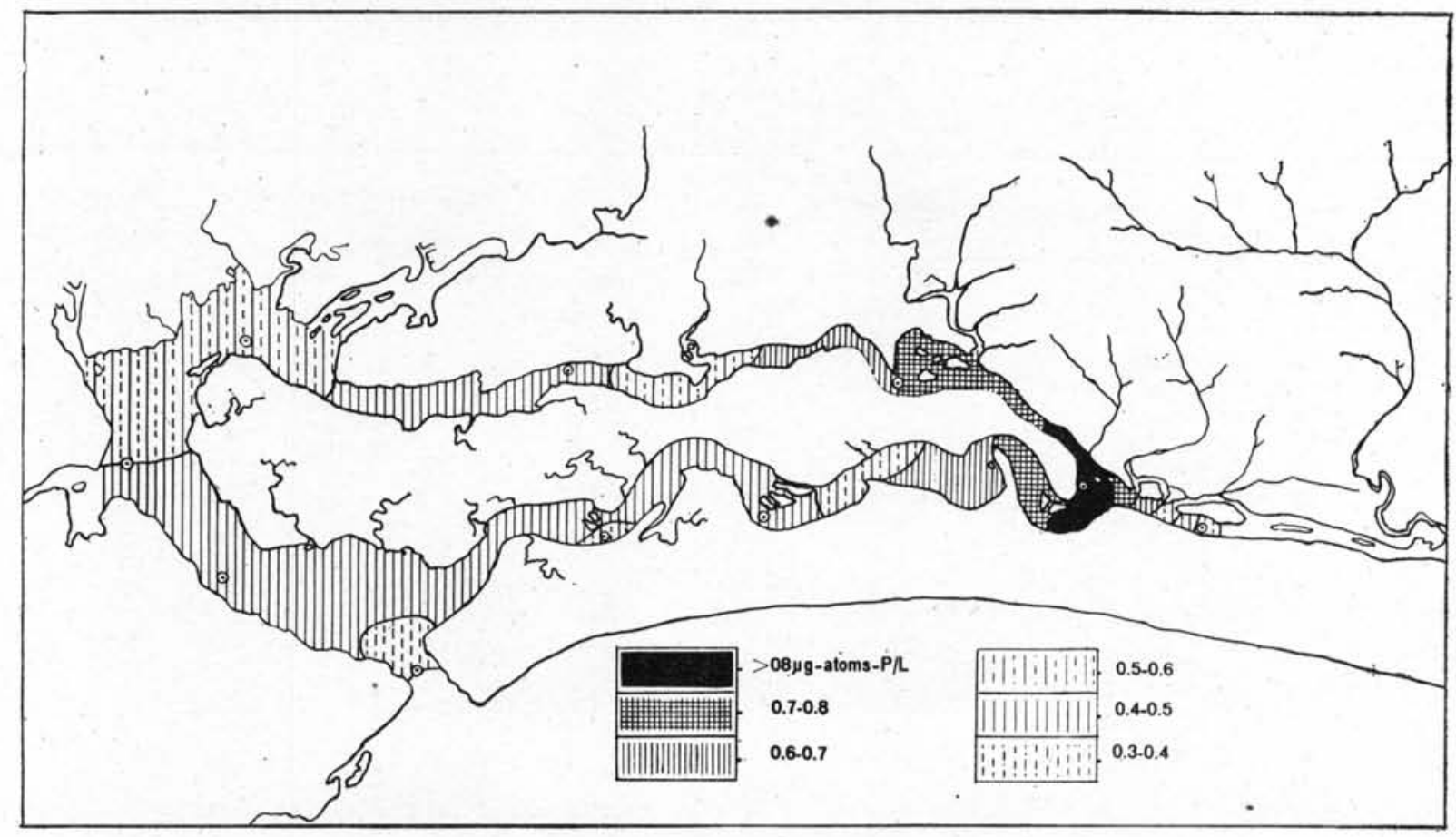

Fig. 13 - Distribution of phosphate-P in Cananéia lagoon (bottom layer). 
usually increases actively in summer in the lagoon so that a large consumption of nutrients by the plankton will sometimes cause a lack of nutrients, especially nitrogenous materials. Seasonal variation of the nitrate content in the lagoon water is very large. A fairly high amount of nitrate, as much as 6-12 $\mu$ g-atoms- $\mathrm{N} / \mathrm{l}$, in winter (June), while an explosive increase of phytoplankton population in summer, causes sometimes an almost complete consumption of nitrogenous nutrients as in the case mentioned above.

Characteristic accumulation of nitrates in the water of the inner region will illustrate the follow- ing hydrographic characteristic of the interior water of the lagoon.

Most of the nutrient substances, probably as suspended detritus, will be carried in from the neighbouring fresh-water system and accumulate at the northern portion of the lagoon. This is shown at St. 5 and 3, where horizontal movement of the water with the tidal fluctuations is not so strong as to wash out the accumulation of suspended materials in the water. Subsequently in such sheltered areas (like the above) an active decomposition by bacteria would turn the organic suspension into a form usable by the plankton population.

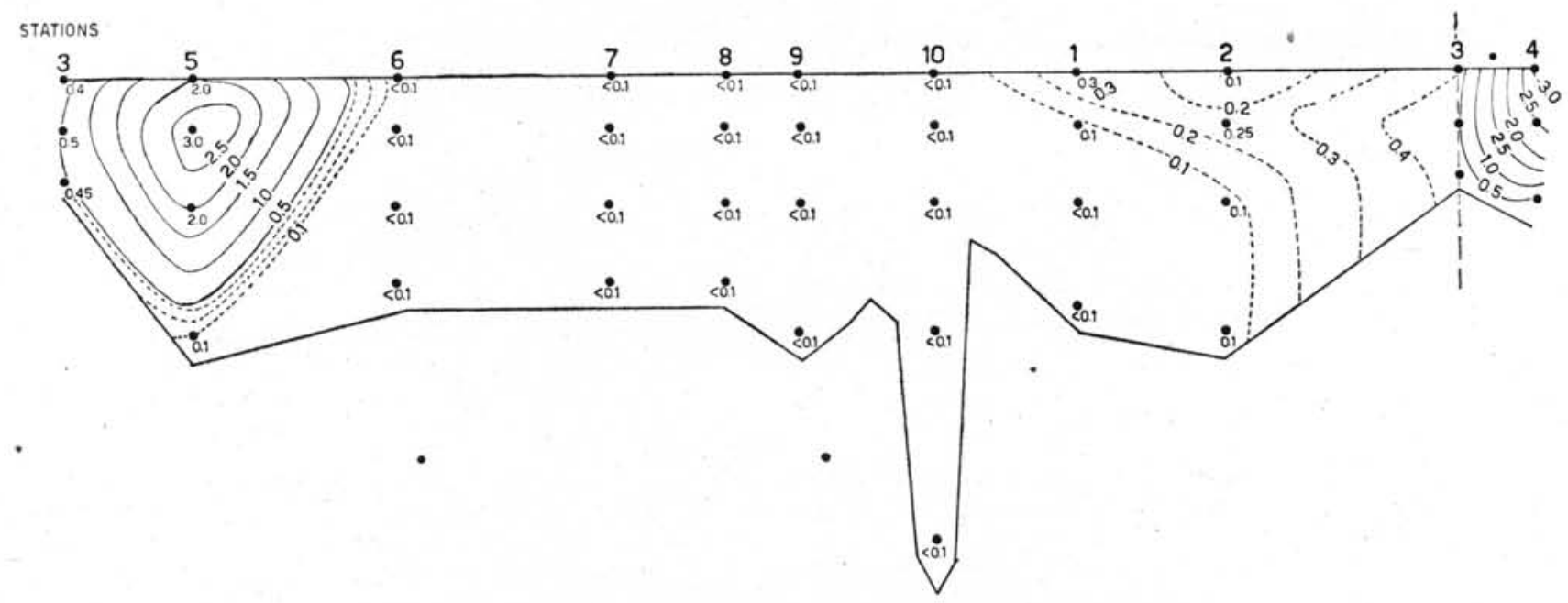

Fig. $14-$ Nitrate-N ( $\mu$ g-atoms N/1), Cananéla lagoon.

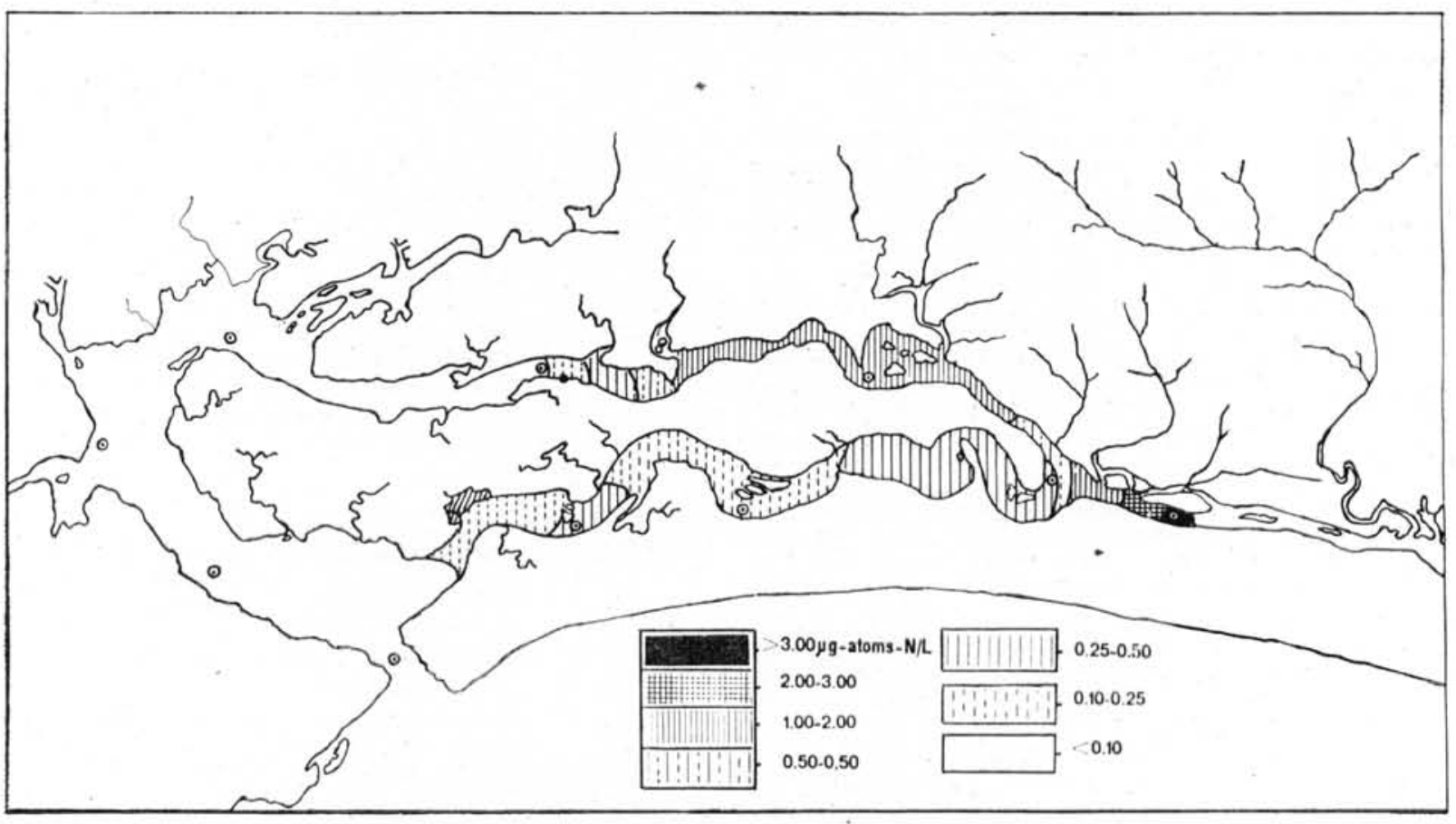

Fig. 15 - Distribution of nitrate-N in Cananéla lagoon (surface layer). 
Another contribution of the neighbouring freshwater system to the nutrient enrichment of the whole lagoon was observed in the first serial investigation carried out in January 1958 at the mouth of the Rio Nóbrega, one of the so-called "marigot" (KaTo, 1966b). A good amount of nitrate, as much as $3.0 \mu$ g-atoms- $\mathrm{N} / \mathrm{l}$ on the average was observed during the investigation. The above amount is rather high compared to the small quantity of nitrate observed in the outer lagoon water. Therefore the fertilization of the lagoon is probably brought about by the supply of a large amount of nutrients materials by the mangrove rivers or "marigots".

\section{ACKNOWLEDGEMENTS}

The author is particularly indebted to Prof. W. BESNARD, Director of the Oceanographic Institute of the University of São Paulo, for his suggestions and encouragement during this work. Thanks are also due to Dr. I. Emilsson, Dr. M. Furuya and Dr. V. SADowSKY of the Institute for their cooperation and to Dr. T. K. S. BJöRNBERG who revised this manuscript. The author thanks the National Council of Research of Brazil for the fellowship.

\section{R E S U M O}

O presente trabalho, sôbre os resultados de estudos que foram realizados periòdicamente no sistema hidrográfico de Cananéia, Estado de São Paulo, em 1958, descreve as características da distribuição dos constituintes químicos das águas daquela região, segundo observações levadas a efeito em fevereiro de 1958.

A água oceânica (salinidade $34 \%$; $4,5 \mathrm{ml} / 1 \mathrm{O}_{2}$; $\mathrm{pH} \quad 8,4 ; 0,1 \mu$ g-átomos-nitrato-N/1; $0,3 \mu$ g-átomosfosfato-P/1 e $4 \mu$ g-átomos-silicato-Si/1) penetra na região lagunar durante a maré alta, através da barra de Cananéia. A maior parte dessa água toma a direção oeste, pela baía de Trapandé, represando a água lagunar para o norte, enquanto uma quantidade menor entra pela parte leste, pelo chamado mar de Cananéia, no que é aparentemente impedida pela exigüidade da passagem. Na parte interna da regiào lagunar, o aumento do nivel das águas depende, aparentemente, de um acúmulo de água dos tributários, causado pelas ondas de maré.

A queda do nível do mar durante a maré baixa, puxa para fora as águas da região lagunar e comumente observa-se uma grande velocidade do fluxo da água, que sai através da estreita passagem do mar de Cananéia.

$\mathrm{Na}$ parte interna da região lagunar, quando diminui o movimento horizontal das águas, devido às marés, surge um estado dé redução na camada de fundo, devido à decomposição de matérias orgânicas em depósito, causada pelas bactérias. Sendo assim, observa-se uma baixa considerável do oxigênio na água imediatamente acima do fundo. Nas águas de superfície, na mesma estação, a quantidade de oxigênio dissolvido alcança quase o ponto de saturação. A ação das bactérias é muito importante para - metabolismo da região lagunar. A devolucão de nutrientes, para a água, sem dúvida alguma, contribui de forma eficiente para o enriquecimento da produção de fitoplâncton.

\section{REFERENCES}

AB'SÁber, A. N. \& Bernard, W.

1953. Sambaquis da região lagunar de Cananéia. I. Observações geográficas. II. Especulações pré-históricas. Bolm Inst. oceanogr., vol. 4, n. $^{0} 1 / 2$, p. $215-230$, fots.

BEsnaRd, W.

1950a. Considerações gerais em tôrno da região lagunar de Cananéia-Iguape. I. Bolm Inst. paul. oceanogr., vol. $1, \mathrm{n}^{\circ}$ 1, p. 9-26, figs.

1950b. Consideracões gerais em tôrno da região lagunar de Cananéia. II. Diversos aspectos atuais da região lagunar. Ibid., vol. 1 , n. ${ }^{\circ} 2$, p. $3-28$, figs.

Bigarella, J. J.

1954. Nota sôbre os depósitos arenosos recentes do litoral sul-brasileiro. Bolm Inst. oceanogr., vol. 5 , n. $^{\circ} 1 / 2$, p. $233-240$, figs.

Carvalho, J. P.

1950. O plâncton do Rio Maria Rodrigues (Cananéia). I. Diatomáceas e dinoflagelalados. Bolm Inst. paul. oceanogr., vol. 1 , n. ${ }^{\circ} 1$, p. $27-43$, figs., tabs.

Carvalho, J. P. \& Chermont, E. M. L.

1952. Sôbre alguns Foraminifera da costa do Estado de São Paulo. Bolm Inst. oceanogr., vol. 3 , n. $^{0} 1 / 2$, p. $77-100$, est.

КАто, K.

1966a. Studies on calcium content in sea water. III. Calcium in the waters of Cananéia lagoon and its adjacent regions, State of São Paulo, Brazil. Bolm Inst. oceanogr., vol. 15, n. ${ }^{\circ} 1$, p. 41-45.

1966b. Geochemical studies on the mangrove region of Cananéia, Brazil. I. Tidal variations of water properties. Ibid., vol. 15, n. $^{\circ} 1$, p. $13-20$.

MACHADO, L. B.

1950. Pesquisas físicas e químicas do sistema hidrográfico da região lagunar de $\mathrm{Ca}$ nanéia. I. Cursos de água. Nota prévia sôbre os "rios" Maria Rodrigues e Baguaçu. Bolm. Inst. paul. oceanogr., vol. 1, n. $^{\circ} 1$, p. $45-68$, figs. map.

1952. Pesquisas físicas e químicas do sistema hidrográfico da região lagunar de $\mathrm{Ca}$ nanéia. II. Águas de junção. Estudos iniciais das águas comuns da região da ilha da Casca. Nota preliminar sôbre as águas na junção do canal de Ararapira e baía de Trapandé. Bolm Inst. oceanogr., vol. 3, n. $^{\circ} 1 / 2$, p. 55-75, grafs. map.

SADOWSKY, V.

1952. Observações sôbre as modificações em curso na entrada de Cananéia, de sua barra e da região adjacente. I. Desgaste das costas, n. $1-$ Ponta da Trincheira. Ibid., vol. 3 , n. ${ }^{\circ} 1 / 2$, p. 201212, fots. map.

1953. Modificações em curso na entrada da barra de Cananéia. Ibid., vol. 4, n. ${ }^{\circ}$ $1 / 2$, p. 191-214, fots. grafs. map.

1954. Novas contribuições ao estudo da entrada da barra de Cananéia. Ibid., vol. 5 , n. ${ }^{\circ} 1 / 2$, p. $151-178$, fots. grafs. map. 